\title{
Preference for Male Child in Two Semiurban Communities of Pune
}

\author{
Puja Dudeja, Amarjeet Singh, Ashok Jindal, Nidhi Bhatnagar
}

\begin{abstract}
A strong preference for male child exists in our society. Most of the factors that compel or favor son preference are social in origin. A cross-sectional study was conducted to ascertain preference for male child in married females of two semiurban communities in Pune and determinants thereof. Unit of study was a married woman in reproductive age group of 16 to 45 years. A close-ended, pretested structured interview schedule was prepared. Face-to-face interview was conducted with the respondents. Preference for a male child was taken as presence of sex preference in the respondent. Data was analyzed using EPI 2002 software. Preference for male child was present in half of the respondents. Remaining half believed that it is not necessary for each couple to have a male child. Proportion of women with preference for a male child decreased as the educational level of women increased and it was found that there was a significant linear relationship between literacy status and son preference $(p<0.05)$. Significantly more $(64 \%)$ of joint family respondents had son preference than nuclear family $(40 \%)$. The odds of a respondent from a joint family having a son preference were 2.6 times that of a respondent in nuclear $(p<0.05)$. Hindus had significantly more preference for male child as compared to non-Hindus. The most common reason for desire to have a male child was 'an expectation of security in old age'. Others reasons included 'to perform last rites' and 'to make in-laws happy'.
\end{abstract}

Keywords: Son preference, Sex selection, Family planning, Female literacy, Joint family.

How to cite this article: Dudeja $P$, Singh $A$, Jindal $A$, Bhatnagar N. Preference for Male Child in Two Semiurban Communities of Pune. J Postgrad Med Edu Res 2013;47(3): 144-147.

\section{Source of support: Nil}

Conflict of interest: None declared

\section{INTRODUCTION}

In India, a strong son preference is seen even today. ${ }^{1-3}$ In fact, several investigators have argued that preference for male children helps to sustain high fertility and are likely to act as a potential obstacle to rapid fertility decline. Most of the factors that compel people to favor a male offspring are social in origin. ${ }^{4}$ Son preference has also been reported to be an important reason for use of prenatal sex identification tests and sex specific abortions. ${ }^{5}$ Women's future decisions to accept contraception are clearly linked to the number of living sons among her surviving children. ${ }^{6,7}$

In a society experiencing fertility transition, the preference for at least two surviving sons is going to emerge as a major constraint for the family planning program, especially in the North. ${ }^{8-10}$ In the light of these findings, it appears that further increase in the contraceptive prevalence rates in the country may become increasingly more difficult unless there is a decline in the desire for male children. Thus, it is important that the government instead of propagating the two-child family norm across the board emphasizes the policies that actively enhance women's status and changes the attitude of people toward female children. It was estimated that if son preference were completely eliminated, contraceptive acceptance would increase by approximately $4 \%$ and sterilization by $5 \%$ for the country as a whole. ${ }^{11}$ Any such effort should be based on the prevailing status of son preference in a society. Against this background present study was conducted with the following objectives:

\section{OBJECTIVES}

1. To ascertain preference for male child in married females of two semiurban communities in Pune and determinants thereof.

2. To find out the influence of socioeconomic and demographic features in the family planning practices of the study population.

\section{MATERIALS AND METHODS}

The study was carried out at two semiurban communities, Wanwadi and Chimta basti in Pune. Medical services are available to the community through Command Hospital (Southern Command), Cantonment General Hospital and private practitioners. Department of Preventive and Social Medicine of Armed Forces Medical College (AFMC), Pune, provides Family Health Advisory Services including OPD care to the community through mobile clinics and visits by medicosocial workers. Patients requiring further treatment are referred to Command Hospital Southern Command (located within a distance of $2 \mathrm{~km}$ from these communities). Mahadji Shinde High School provides free education along with uniforms and books.

The respondents were selected from the communities in the urban field practice area of AFMC. Both the communities were similar in their socioeconomic and demographic characteristics. There are grocery, cycle repair, stationery, meat, gift items and pharmacy shops in these communities. There is a temple each in both these communities and a mosque in Wanwadi bazaar. 
Census details of these communities were taken from the medicosocial workers working in the area. These are semiurban communities with estimated population of 1956 and 557 respectively. Unit of study was a married woman in reproductive age group of 16 to 45 years. The investigator at the respondent's house conducted the interviews personally. The women were explained about the objectives of the study and an informal verbal consent was obtained. All women, both participants as well as nonparticipants in the study were offered health education, counseling, contraceptive and referral services. A closeended, pretested structured interview schedule was prepared. Face-to-face interview was conducted with the respondents and responses were noted. Preference for a male child was taken as presence of sex preference in the respondent. Data was analyzed using EPI 2002 software.

\section{RESULTS}

Preference for male child was present in half of the respondents. Remaining half believed that it is not necessary for each couple to have a male child (Table 1). Proportion of women with preference for a male child decreased as the educational level of women increased and it was found that there was a significant linear relationship between literacy status and son preference $(\mathrm{p}<0.05)$ (Table 2). Significantly more (64\%) of joint family respondents had son preference than nuclear family (40\%). The odds of a respondent from a joint family having a son preference were 2.6 times that of a respondent in nuclear $(\mathrm{p}<0.05)$ (Table 3). Hindus had significantly more preference for male child as compared to non-Hindus (50 Muslim and 17 Christian respondents) (Table 4). The most common reason for desire to have a male child was 'an expectation of security in old age'. Others reasons included 'to perform last rites' and 'to make inlaws happy’ (Table 5).

\section{DISCUSSION}

Son preference in India is a well-documented phenomenon. Its implications in the form of a skewed sex ratio, female feticide and higher child mortality rates for girls have drawn a lot of research and policy attention. ${ }^{12,13}$ But what is less known are the underlying determinants of son preference and its implications for living girls. The traditional preference for sons is deeply rooted in the social structure of the Indian society.

The child sex ratio in our country has steadily declined from 976 in 1961 to 927 in 2001 and further to 914 in 2011. This indicates that India is still averse to daughters being born. In fact this represented a 'cultural lag' where, on one hand even poor people in India use cell phones, ride metros, take advantage of latest gizmos while on the other hand their attitude dates back to cave age, to same old patriarchal mindset when it comes to dealing with the sex composition of the family. In an environment with strong son preference, couples continue to make effort (the woman getting pregnant again and again) until they get the desired numbers of male babies. The support of biotechnology (ultrasound) has made it for couples to diagnose the sex of unborn babies and achieve desirable sex composition of the family through female feticide.

\begin{tabular}{l} 
Table 1: Son preference of respondents \\
$\begin{array}{lll}\text { Is it necessary to have a } \\
\text { male child? }\end{array}$ \\
\begin{tabular}{lll} 
Yes & Frequency (\%) & \\
\hline No & $134(50.19)$ & $(44.20-56.17)$ \\
\hline
\end{tabular} \\
\hline
\end{tabular}

\begin{tabular}{lllr}
\multicolumn{3}{l}{ Table 2: Literacy status of respondents and son preference } \\
\hline \multirow{2}{*}{ Literacy status } & \multicolumn{2}{c}{ Sex preference } & \multirow{2}{*}{ Total } \\
\cline { 2 - 3 } & Present & Absent & \\
\hline Illiterate & $34(0.77)$ & $10(0.33)$ & 44 \\
Primary & $26(0.57)$ & $19(0.43)$ & 45 \\
Middle & $39(0.47)$ & $43(0.53)$ & 82 \\
High school and above & $35(0.36)$ & $61(0.64)$ & 96 \\
\hline Total & 134 & 133 & 267 \\
\hline
\end{tabular}

Chi-square value: 21.413 ; $d f=3$; p-value: $0.0000(<0.05)$

\begin{tabular}{llll}
\multicolumn{3}{l}{ Table 3: Type of family of respondent and son preference } \\
\hline \multirow{2}{*}{ Type of family } & \multicolumn{2}{c}{ Sex preference } & Total \\
\cline { 2 - 3 } & Present & Absent & \\
\hline Joint & $77(64.16)$ & $43(35.84)$ & 120 \\
Nuclear & $60(40.81)$ & $90(59.19)$ & 147 \\
\hline Total & 134 & 133 & 267 \\
\hline
\end{tabular}

Chi-square value: $14.58 ; \mathrm{df}=1 ; \mathrm{p}$-value: 0.0000782

Table 4: Religion of respondent and sex preference

\begin{tabular}{lllr}
\hline \multirow{2}{*}{ Religion } & \multicolumn{2}{c}{ Sex preference } & Total \\
\cline { 2 - 3 } & Present & Absent & \\
\hline Hindu & $106(52.21)$ & $97(47.79)$ & 203 \\
Non-Hindus & $28(43.75)$ & $36(56.25)$ & 64 \\
\hline Total & 134 & 133 & 267 \\
\hline
\end{tabular}

Chi-square value: $7.70 ; \mathrm{df}=1 ; \mathrm{p}$-value: 0.021

Table 5: Reasons for son preference

\begin{tabular}{ll} 
Reason for having male child & Frequency (\%) \\
\hline Security in old age & $71(52.98)$ \\
To run the family name & $20(14.92)$ \\
Bring dowry at the time of marriage & $33(24.62)$ \\
To run family business & $05(03.73)$ \\
Others & $05(03.73)$ \\
\hline Total & 134 \\
\hline
\end{tabular}


The present study documented decreased son preference with increase in literacy level of females. This is consistent with various other studies which have documented a significant negative relationship between female education and the use of contraception. ${ }^{14,15}$ Education leads to liberation and takes the society on the path of progression. Thus, an educated and well informed society has less son preference. Half of the respondents in our study asserted that it was necessary to have a male child. This reflects ambivalent attitude of the society for having a girl child. There is an ambiguity in education and son preference relationship. On one hand, education of women gives her the autonomy and better control over contraception and on the other hand it gives them better ability to manipulate the desirable sex composition of the family by use of biotechnology. ${ }^{16}$

The son preference was significantly high in respondents staying in a joint family. Women are dominated by the likes and dislikes of their in-laws in joint families. This dominance has a tremendous role in the opinion molding of the couple. The power of a joint family system has been demonstrated albeit negatively when it comes to son preference. The family decisions override the desires/choice of the couple or more specifically of the female partner. The nuclear families in the modern society have given immense freedom to the couple from the traditions, orthodoxy and ways of life that the old system was ridden with. In contrast to joint families women in nuclear families have better expression and more say in family matters. They have the opportunity to create an identity of their own. In nuclear families, women are not blamed for not bearing a male child.

The preference for a male child was more in Hindus as compared to Muslims and Christians. Among Hindus, it is largely believed that only a son can light the funeral pyre and offer prayers to ancestors. Son remains part of the family, whereas the daughter becomes a part of another family. Hindus believe that 'kanyadaan' (giving away of a daughter in marriage) is a necessary for spiritual obligation. Most Hindus have a belief that only a son can provide oldage security. ${ }^{17}$ The belief that the daughter does not belong to her paternal/maternal home is deeply entrenched. The birth of a son is a cause for celebration, while the birth of a daughter is met with silence and shame. Sons also carry on of the family name, provide the income and also provide efficient labor. ${ }^{18}$ It is strongly believed by some Hindus that if a man died without a son, his lineage was broken and all his ancestors and unborn dependents would die with him. The wives, who were not able to give their husbands sons, could expect them to take second wives.

The commonest reported reason for having son preference was social security in old age. Old age is accompanied with reduced capacity to work, to earn and consequent inability to earn coupled with lack of social security. The work opportunities reduce progressively with ageing. There is lack of adequate social security in the form of pension schemes, medical benefits and old age homes in our country. The society does not accept the practice of parents living in daughters' homes in old age. Hence, even in the 21st century, people do not celebrate when a daughter is born; these reasons prevail and have caused aversion toward girl's birth. In contrast, the old are cared for in the Western world through government schemes and strong social security system. This makes the preference for male child low in those societies. Many of the developed countries in the West do not show any evidence of son preference or daughter neglect. ${ }^{19}$ It has been projected that some of the traditional and cultural reasons for preferring sons over daughters would erode with economic expansion, higher literacy rates and exposure. Son preference has serious negative effects on women's health, fertility choices, and future well being of girls. Policy makers need to take into consideration the complex interplay of economics, religion, traditions, customs, and the inferior status of women in order to address this grave issue. While interpreting our study results it may be kept in mind that respondents might have given mainly socially desirable response.

\section{REFERENCES}

1. Singh AJ, Arora AK. Status of sex determination tests in North India villages. Indian J Community Med 2006;31:41-43.

2. Kishwar M. When daughters are unwanted. Sex determination tests in India. Manushi 1995;86:15-22.

3. Khanna SK. Prenatal sex determination. A new family building strategy. Manushi 1995;6:23-29.

4. Singh AJ, Bandyopadhyay S. Sex selection through traditional drugs in rural North India. Indian J Community Med 2007;32: 32-34.

5. Yi Z, Ping T, Baochang G. Causes and implications of the recent increase in the reported sex ratio at birth in China. Popul Dev Rev 1993;19:283-302.

6. Kathryn M, Yount R, Langsten K. The effect of gender preference on contraceptive use and fertility in rural Egypt. Stud Fam Plann 2000;31(4):290-300.

7. Johansson A, Nguyen, Thi Hoa H. Population policy, son preference and the use of IUDs in North Vietnam. Reprod Health Matters 1998;6(11):66-76.

8. Nag M. Sex preferences in Bangladesh, India and Pakistan and its effect on fertility. Demography India 1992;20:163-85.

9. Malhi P. Impact of women's education on sex preferences, value and aspirations for children: Evidence from Haryana. Man and Development 1993;15:46-62.

10. Rajaretnam T, Deshpande RV. The effect of sex preferences on contraceptive use and fertility in rural South India. Int Fam Plan Perspect 1994;20(3):88-95.

11. Malhi P, Jerath J. Is son preference constraining contraceptive use in India? Guru Nanak J Sociol 1997;18(2):77-92. 
12. Imam Z. India bans female feticide. BMJ 1994;309(6952):428.

13. Subramanian $S$, Selvaraj S. Social analysis of sex imbalance in India: Before and after the implementation of the Pre-Natal Diagnostic Techniques (PNDT) Act. J Epidemiol Community Health 2009;63(3):245-52.

14. Visaria L. Regional variations in female autonomy and fertility and contraception in India. Gujarat Ins Develop Res 1993:50.

15. Saleem S, Bobak M. Women's autonomy, education and contraception use in Pakistan: A national study. Reprod Health 2005;2(1):8.

16. Oldenburg P. Sex ratio, son preference and violence in India: A research note. Economic and Political Weekly 1992:2657-62.

17. Ahmad N. Female feticide in India. Issues Law Med 2010 Summer;26:13.

18. Dubuc S. Son preference and prenatal sex selection: Recent trends in the UK South Asian diaspora. In proceedings of the European Population Conference 2012, Stokholm 15 June 2012, in session 'Gender issues in sexuality and reproductive health.'

19. Mitra A. Son preference in India: Implications for gender development. University of Oklahoma 2011.

\section{ABOUT THE AUTHORS}

\section{Puja Dudeja (Corresponding Author)}

PhD Scholar, Department of School of Public Health, Postgraduate Institute of Medical Education and Research, Chandigarh, India e-mail: puja_dudeja@yahoo.com

\section{Amarjeet Singh}

Professor, Department of School of Public Health, Postgraduate Institute of Medical Education and Research, Chandigarh, India

\section{Ashok Jindal}

Professor, Department of Community Medicine, Armed Forces Medical College, Pune, Maharashtra, India

\section{Nidhi Bhatnagar}

Senior Resident, Department of School of Public Health, Postgraduate Institute of Medical Education and Research, Chandigarh, India 